\title{
ДОСВІД ЗАСТОСУВАННЯ ТЕХНОЛОГІЇ ЗМІШАНОГО НАВЧАННЯ ПРИ ФОРМУВАННІ ІНШОМОВНОЇ КОМУНІКАТИВНОЇ КОМПЕТЕНТНОСТІ СТУДЕНТІВ
}

\begin{abstract}
Іншомовна комунікативна компетентність є однією з обов'язкових складових частин професійної компетентності сучасного фахівця. За умов викликів сьогодення застосування технології змішаного навчання для формування згаданої компетентності набуває надзвичайного поширення в освітньому процесі, а результати ї̈ впровадження привертають увагу науковиів. Подана технологія поєднує аудиторну роботу з роботою в ијифровому навчальному середовищі. Якщчо очна робота передбачає фізичну присутність викладача й студентів в аудиторії, робота в ичифровому навчальному середовищі може відбуватися синхронно або асинхронно. Синхронна взаємодія викладача й студентів проходить у режимі онлайн, асинхронна - не має часових обмежень та обмежень щзодо місия виконання завдань студентами. Позитивним є експериментальний досвід застосування технологї змішаного навчання для формування іншомовної комунікативної компетентності студентів, зокрема для розвитку навичок читання, аудіювання, письма, монологічного й діалогічного мовлення іноземною мовою. До переваг застосування технологї змішаного навчання науковці відносять: збільшення мотивацї здобувачів освіти до вивчення мови, автономність їхньої роботи, розвиток організаційних навичок $і$ навичок тайм-менеджменту студентів, безперервність роботи, можливість командного й групового виконання завдань, робота із ситуаціями, наближеними до реальних, невимушене й сприятливе середовище для навчання. Змімане навчання надає можливість застосування широкого різноманіття навчальних матеріалів $і$ методів, щзо допомагають у формуванні іншомовної комунікативної компетентності. Використання таких методів і матеріалів збільшують обсяг вивчених лексичних одиниць мови; формують граматичні навички; поліпшують вимову здобувачів освіти. Проте ефективне застосування технології змішаного навчання потребує відповідної мовної підготовки студента, його ичифрової грамотності й доступу до мережі Інтернет.
\end{abstract}

Ключові слова: технологія, змішане навчання, іншомовна комунікативна компетентність, цифрове навчальне середовище.

Nataliia BURMAKINA, orcid.org/0000-0002-4960-5276 Candidate of Pedagogical Sciences, Senior Lecturer at the Department of Foreign Languages Polissia National University (Zhytomyr,Ukraine) burmakinanatalia@gmail.com

\section{EXPERIENCE IN THE USE OF BLENDED LEARNING TECHNOLOGY FOR FOREIGN LANGUAGE COMMUNICATIVE COMPETENCE FORMATION OF STUDENTS}

Foreign language communicative competence is the necessary constituent in the structure of professional competence of today's experts. In the face of current challenges the application of blended learning for formation of this competence has received growing attention from academics. The technology combines class or face-to-face learning (traditional learning environment) and e-learning (computer learning environment). E-learning can have either synchronous or asynchronous character. In case of synchronous e-learning students and a teacher cooperate online. Under asynchronous conditions time and place of e-learning are not determined and students can work at any convenient time and place, where Internet access is available. Experimental experience in the use of blended learning in different countries including Ukraine demonstrates positive effect on foreign language communicative formation, in particular, for the development of reading, listening, writing and speaking skills of students. Advantages of blended learning are as follows: motivation increase, students' autonomy, the development of organizational and time-management skills, learning continuity, opportunity for team and group work, the application of real life situations, favorable environment for language learning. 
Blended learning gives the access to great variety of teaching methods and materials which can assist the formation of foreign language communicative competence. The application of such methods and materials can increase student's vocabulary, develop student's grammar skills and form student's pronunciation. However, blended learning application can be effective in case of student's appropriate initial language level, digital literacy and opportunity to have access to the Internet.

Key words: technology, blended learning, foreign language communicative competence, e-learning environment.

Постановка проблеми. Однією зі складових частин професійної компетентності сучасного фахівця $\epsilon$ сформована іншомовна комунікативна компетентність. Беручи за основу розроблений науковцями комплекс знань і вмінь у складі комунікативної компетентності (Гавриляк, 2019: 71), можемо зазначити, що іншомовна комунікативна компетентність фахівця містить: знання норм i правил іншомовного спілкування (ділового, повсякденного тощо); високий рівень мовленнєвого розвитку, що дозволяє в процесі спілкування вільно передавати й сприймати інформацію; розуміння невербальної мови спілкування; уміння вступати в контакт із людьми з урахуванням їх статевих, вікових, соціокультурних, статусних характеристик; уміння поводитися адекватно ситуації та використовувати іiі специфіку для досягнення власних комунікативних цілей; уміння впливати на співрозмовника; здатність правильно оцінити співрозмовника як особистість та обирати власну іншомовну комунікативну стратегію в залежності від цієї оцінки; здатність викликати в співрозмовника позитивне сприйняття власної особистості. Таким чином, формування іншомовної комунікативної компетентності студентів $є$ тривалим процесом, ефективність якого залежить від обраних технологій навчання.

У результаті розвитку цифрових технологій і за умов виклику сьогодення в системі освіти все частіше застосовується технологія змішаного навчання. Подана технологія передбачає «поєднання аудиторної роботи з роботою за допомогою цифрового навчального середовища, водночас два методи спрямовані на доповнення один одного» (Banditvilai, 2016).

Аналіз досліджень. Застосування технології змішаного навчання в освітньому процесі стала кочовою в роботах таких науковців: С. Березенської, Н. Олійник, Н. Рашевської, А. Столяревської, Г. Ткачук тощо. Використання змішаного навчання для формування іншомовної комунікативної компетентності стало темою досліджень багатьох вітчизняних науковців (О. Ісаєва, О. Милик, І. Мисків, І. Хміляр, М. Шумило) й цілого ряду іноземних дослідників (H. Abdullah, C. Banditvilai, B. Isiguzel, M. Permadi, F. Sholihah, A. Umamah тощо).
Мета статті - проаналізувати світовий досвід застосування технології змішаного навчання під час формування іншомовної комунікативної компетентності здобувачів освіти, розглянути переваги й недоліки згаданої технології.

Виклад основного матеріалу. Змішане навчання відбувається шляхом комбінації аудиторних занять і роботи в цифровому освітньому середовищі. Очне навчання передбачає фізичну присутність викладача й студентів в аудиторії. Цифрове навчальне середовище пропонує синхронний або асинхронний характер роботи. Синхронний характер - це співпраця в режимі реального часу, тобто учасники навчального процесу знаходяться в онлайн-режимі одночасно. Асинхронний характер не має часового обмеження або вимоги до місця виконання завдань (Isiguzel, 2014: 109), що є беззаперечною перевагою під час формування іншомовної комунікативної компетентності, адже надає студентові можливість вивчати іноземну мову в зручний час і в зручному місці, забезпечуючи право на освіту всім категоріям студентів, зокрема з особливими освітніми потребами. Крім того, змішане навчання дозволяє обирати широке різноманіття навчальних матеріалів і методів, що сприяє розвитку навичок аудіювання, читання, говоріння та письма. Методи, що застосовуються в разі змішаного навчання, містять лекцію, дискусію, гру, вебінар, конференцію, метод case-study тощо, все це створює невимушене середовище для вивчення мови, залучає до активної участі в навчанні. Матеріалами для формування іншомовної комунікативної компетентності слугують: освітні програми; наукова й повсякденна інформація, розміщена в мережі Інтернет, Facebook, Twitter, YouTube; чати, блоги, подкасти. Застосування таких навчальних матеріалів робить ефективним процес формування іншомовної комунікативної компетентності, оскільки надає можливість спілкування як усного, так і письмового з викладачем, одногрупниками й навіть безпосередньо з носієм іноземної мови; відкриває доступ до оригінальних текстів; формує правильну вимову; покращує сприйняття інформації іноземною мовою; збільшує обсяг вивчених лексичних одиниць, розвиває граматичні навички; забезпечує соціокультурне наповнення занять. 
Найефективнішими для формування іншомовної комунікативної компетентності науковці, які проводили експериментальні дослідження в цьому питанні, виокремили: подкасти; вебсайти; відеоігри; електронні словники; електронне портфоліо (Abdullah, 2015).

Відповідно до проведених експериментальних досліджень, технологія змішаного навчання має позитивний вплив на розвиток навичок іншомовного спілкування, аудіювання, читання, письма в студентів. Так, експериментально доведено, що застосування екстенсивного аудіювання (що передбачає використання різноманітних аудіо / відеоматеріалів, інтерв'ю тощо 3 однієї теми) (University of Islam Malang, Індонезія) покращує показники сформованості навичок аудіювання в студентів. Водночас найвищі результати досягаються за умов невеликого часового інтервалу між аудиторною роботою та роботою в цифровому середовищі (Sholihah et al., 2018). Експериментальне впровадження змішаного навчання для вдосконалення навичок монологічного й діалогічного мовлення (Politeknik Indonusa Surakarta, Індонезія) також показало позитивний результат. До того ж завдяки роботі в цифровому навчальному середовищі в студентів зникав страх помилитися під час застосування мовленнєвих конструкцій іноземною мовою та невпевненість у власних силах (Syaifudin, 2017). Змішане навчання максимізувало можливості читання іноземною мовою студентів (Ma Chung University, Індонезія), а сам процес читання став для здобувачів освіти, за їхньою оцінкою, позитивним і цікавим (Djiwandono, 2018).

Письмові результати студентів із курсу англійської мови (Hawassa University, Ефіопія) після застосування змішаного навчання засвідчили вдосконалення граматики, орфографії в роботах студентів; збільшення словникового запасу; поліпшення самої логічності й структури письмових творів. Цей позитивний результат викладачі університету пов'язують із застосуванням мультимедіа, аудіотекстів, анімації, слайдів PowerPoint, що враховували індивідуальні особливості студентів; створенням інтерактивного й невимушеного середовища, що заохочувало до комунікації, співпраці й командної роботи; допомогою в організації стратегії самонавчання, застосуванням методів самооцінки (Getta, Olango, 2016).

Окремою перевагою застосування технології змішаного навчання можна назвати збільшення мотивації та зацікавленості студентів до вивчення іноземної мови. Так, дослідження, проведене в Туреччині (Nevsehir Hac1 Bektas Veli University,
Туреччина), щодо відмінностей у результатах опанування німецькою мовою як іноземною між експериментальною (за умов змішаного навчального середовища) й контрольною (за умов традиційного навчального середовища) групами довело, що студенти експериментальної групи мають більшу вмотивованість до подальшого вивчення дисципліни (Isiguzel, 2014).

Проте експериментальне дослідження, проведене в університеті Франції (Nantes University, Франція) виявило цікаву закономірність - результат застосування технології змішаного навчання залежить від початкового рівня володіння іноземною мовою студентами. «У змішаній системі навчання дистанція працює як фільтр» (NarcyCombes, McAllister, 2011). Значний відсоток студентів із низьким початковим рівнем володіння мови взагалі припинили відвідувати курс «Іноземна мова». Студенти з вищим початковим рівнем значно поліпшили свої лінгвістичні показники після застосування вказаної технології (Narcy-Combes, McAllister, 2011).

Аналіз наукових робіт показав, що немає абсолютних вимог до організації навчання за змішаною технологією. Кількість аудиторних занять, кількість синхронних та асинхронних занять у цифровому середовищі, кількість студентів у групах, основна навчальна платформа, на якій застосовується технологія змішаного навчання, можуть відрізнятися в залежності від освітньої програми й обраного підходу викладача.

Так, наприклад, змішана програма вивчення мови, реалізована в Нантському університеті, поєднувала дві години очних занять і дві-три години навчання за допомогою цифрового середовища. Аудиторні години містили роботу викладача протягом однієї години в цілому класі із сорока п'ятьма учнями й однієї години в групах по п’ятнадцять студентів. Цифрове навчання базувалося на віртуальній освітній платформі 3 відкритим кодом Moodle i складалося 3 двох окремих просторів:

- простір, що містив рекомендації з підготовки до роботи з мовним матеріалом (результати виявили, що до цього простору зверталося лише $22 \%$ студентів);

- простір самонавчання, який містив інтерактивні граматичні, лексичні завдання та вправи на аудіювання (цей простір відвідували, відповідно до досліджень, лише $20 \%$ слухачів курсу).

Водночас одна категорія студентів назвала такі переваги змішаного навчання: можливість працювати у вибраному темпі; збільшення відповідальності за особисті досягнення в опануванні мовою; автономність роботи; розвиток організаційних 
навичок; розвиток навичок тайм-менеджменту; збільшення власних зусиль для виконання завдання; робота із ситуаціями, наближеними до реальних. Недоліками, на думку другої категорії студентів, стали: труднощі самостійної роботи; труднощі організації графіку роботи; недостатня кількість годин роботи безпосередньо 3 викладачем; труднощі командної / групової роботи (Narcy-Combes, McAllister, 2011).

Дослідження, проведене в університеті Таїланду (Kasetsart University, Таїланд), довело, що змішане навчання - цінна концепція, яка дозволяє студентам розвивати й відпрацьовувати навички англійської мови за межами класу в будь-який час і в будь-якому місці, де $\epsilon$ доступ до мережі Інтернет. Додавання цифрового навчання до аудиторного надало студентам можливість автономної роботи й забезпечило децентралізовану передачу знань. Проте студенти, залучені до дослідження, висловили думку, що змішане навчання не може повністю замінити цінну взаємодію з викладачем. «Людська взаємодія забезпечує відчуття соціальної зв'язаності, що неможливо у віртуальному спілкуванні» (Banditvilai, 2016).

Експериментальне дослідження, проведене у Львівському національному медичному університеті імені Данила Галицького (Україна), довело, що до переваг технології цифрового навчання належить гнучкість, безперервність і систематизація формування іншомовної комунікативної компетентності, підвищення мотивації та самоорганізація студентів. Однак упродовж експерименту деякі методи цифрового навчання виявилися складними для студентів. Щоб уникнути таких труднощів, викладачам рекомендовано ретельно, контролюючи обсяг, готувати завдання із чіткими вказівками й роз'ясненнями. Кожне завдання має зацікавити й мотивувати студентів, а для цього необхідно враховувати потреби, інтереси, майбутню професію та практичний досвід здобува- чів освіти. Змішане навчання повинно розвивати навички іншомовного спілкування на основі попередніх знань студентів і за умов інтеграції дисциплін, що вивчаються ними. До недоліків змішаного навчання українські науковці відносять недоступність / повільність Інтернет-з'єднання. На жаль, проведене дослідження констатувало, що далеко не всі студенти вміють працювати із цифровими технологіями, тобто володіють цифровою грамотністю (Isayeva et al., 2020).

Висновки. Проведений аналіз робіт дозволяе нам зробити висновок, що технологія змішаного навчання має значний потенціал для формування іншомовної комунікативної компетентності, адже надає можливість застосовувати різноманітні інноваційні методи навчання, використовуючи безліч матеріалів, що містить мережа Інтернет; забезпечує доступність роботи в зручний час і в зручному місці; збільшує мотивацію, автономність, безперервність вивчення мови; дозволяє використання командної та групової роботи; забезпечує сприятливе середовище для вивчення мови.

Проте застосування змішаного навчання передбачає ряд передумов, 3-поміж яких можна назвати мовну підготовку слухача та його підготовку до роботи із цифровими носіями; доступ до мережі Інтернет. Технологія змішаного навчання потребує й нових акцентів у роботі викладача. Викладач набуває нової ролі фасилітатора в процесі викладання мови, стає «розробником» завдань, що мають відповідати потребам, інтересам студентів, їхньому рівню володіння іноземною мовою. Тобто цифрова й методична грамотність викладача має безпосередній вплив на результат сформованості іншомовної комунікативної компетентності студентів.

Перспективою подальших досліджень $є$ розроблення завдань, спрямованих на розвиток іншомовної комунікативної компетентності за умов застосування технології змішаного навчання.

\section{СПИСОК ВИКОРИСТАНИХ ДЖЕРЕЛ}

1. Гавриляк Л. С. Комунікативна компетентність як складова професійної підготовки сучасного фахівця. $\Lambda О Г О \Sigma$. The art of scientific mind. 2019. № 3. C. 70-73.

2. Abdullah H. Improving Listening Comprehension for EFL Pre-Intermediate Students through a Blended Learning Strategy. World Academy of Science, Engineering and Technology International Journal of Educational and Pedagogical Sciences. 2015. Vol. 9. Number 10. P. 3673-3681. URL: https://publications.waset.org/10004649/improving-listeningcomprehension-for-efl-pre-intermediate-students-through-a-blended-learning-strategy (accessed date: 15.11.2020).

3. Banditvilai C. Enhancing Students' Language Skills through Blended Learning. The Electronic Journal of e-Learning. 2016. Vol. 14. Issue 3. P. 223-232. URL: https://files.eric.ed.gov/fulltext/EJ1107134.pdf (accessed date: 15.11.2020).

4. Djiwandono P. The Effect of Blended Learning on Reading Abilities, Vocabulary Mastery, and Collaboration among University Students. The New English Teacher. 2018. URL: https://www.researchgate.net/publication/323779741 The Effect_of_Blended_Learning_on_Reading_Abilities_Vocabulary_Mastery_and_Collaboration_among_University_Students (accessed date: $15 . \overline{1} 1.2020$ ). 
5. Getta M., Olango M. The impact of blended learning in developing students' writing skills: Hawassa University in focus. African Educational ResearchJournal. 2016. Vol. 4 (2). P. 49-68. URL: https://files.eric.ed.gov/fulltext/EJ1216188. pdf (accessed date: 15.11.2020).

6. Isayeva O., Shumylo M., Khmilyar I., Myskiv I., Mylyk O. Blended Learning in Higher Medical Education: Principles and Strategies of Teaching Foreign Languages. Advanced Education.2020. Issue 14. P. 11-18.

7. Isiguzel B. The Blended Learning Environment of the Foreign Language Learning Process: A Balance for Motivation and Achievement. Turkish Online Journal of Distance Education. 2014. Vol. 15. Number 3. Article 10. P. $108-121$. URL: https://dergipark.org.tr/en/download/article-file/155735 (accessed date: 15.11.2020).

8. Narcy-Combes M., McAllister J. Evaluation of a Blended Language Learning Environment in a French University and its Effects on Second Lnguage Acquisition. Asp. 2011. Vol. 59. P. 115-138. URL: https://journals.openedition.org/asp/2250 (accessed date: 15.11.2020).

9. Sholihah F., Permadi M., Umamah A. Blended Learning and Extensive Listening: A Promising Collaboration to Enhance Listening Skill. ELT-Echo. 2018. Vol. 3. Number 2. P. 88-96. URL: https://www.researchgate.net/publication/335272114 BLENDED_LEARNING_AND_EXTENSIVE_LISTENING_A_PROMISING_COLLABORATION_TO_ENHANCE_

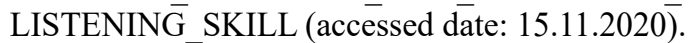

10. Syaifüdin M. Improving Students Speaking Skill by Implementing Blended Learning (Online Learning and Classroom). Jurnal Informa. 2017. Vol. 3. N. 2. P. 30-34. URL: https://informa.poltekindonusa.ac.id/index.php/informa/ article/view/19 (accessed date: 15.11.2020).

\section{REFERENCES}

1. Havrylyak L. S. (2019). Komunikatyvna kompetentnist' yak skladova profesiynoyi pidhotovky suchasnoho fakhivtsya. [Communicative Competence as a Constituent of Professional Training of a Modern Specialist]. 1OГO . The art of scientific mind. № 3. C. 70-73. [in Ukrainian].

2. Abdullah H. Improving Listening Comprehension for EFL Pre-Intermediate Students through a Blended Learning Strategy. World Academy of Science, Engineering and Technology International Journal of Educational and Pedagogical Sciences. 2015. Vol. 9. Number 10. P. 3673-3681. URL: https://publications.waset.org/10004649/improving-listening-comprehension-for-efl-pre-intermediate-students-through-a-blended-learning-strategy (accessed date: 15.11.2020).

3. Banditvilai C. Enhancing Students' Language Skills through Blended Learning. The Electronic Journal of e-Learning. 2016. Vol. 14. Issue 3. P. 223-232. URL: https://files.eric.ed.gov/fulltext/EJ1107134.pdf (accessed date: 15.11.2020).

4. Djiwandono P. The Effect of Blended Learning on Reading Abilities, Vocabulary Mastery, and Collaboration among University Students. The New English Teacher. 2018. URL: https://www.researchgate.net/publication/323779741_The_ Effect_of_Blended_Learning_on_Reading_Abilities_Vocabulary_Mastery_and_Collaboration_among_University_Students (accessed date: $15 . \overline{11} 1.2020$ ).

5. Getta M., Olango M. The impact of blended learning in developing students' writing skills: Hawassa University in focus. African Educational ResearchJournal. 2016. Vol. 4 (2). P. 49-68. URL: https://files.eric.ed.gov/fulltext/EJ1216188. pdf (accessed date: 15.11.2020).

6. Isayeva O., Shumylo M., Khmilyar I., Myskiv I., Mylyk O. Blended Learning in Higher Medical Education: Principles and Strategies of Teaching Foreign Languages. Advanced Education.2020. Issue 14. P. 11-18.

7. Isiguzel B. The Blended Learning Environment of the Foreign Language Learning Process: A Balance for Motivation and Achievement. Turkish Online Journal of Distance Education. 2014. Vol. 15. Number 3. Article 10. P. 108-121. URL: https://dergipark.org.tr/en/download/article-file/155735 (accessed date: 15.11.2020).

8. Narcy-Combes M., McAllister J. Evaluation of a Blended Language Learning Environment in a French University and its Effects on Second Lnguage Acquisition. Asp. 2011. Vol. 59. P. 115-138. URL: https://journals.openedition.org/ asp/2250 (accessed date: 15.11.2020).

9. Sholihah F., Permadi M., Umamah A. Blended Learning and Extensive Listening: A Promising Collaboration to Enhance Listening Skill. ELT-Echo. 2018. Vol. 3, Number 2. P. 88-96. URL: https://www.researchgate.net/publication/335272114_BLENDED_LEARNING_AND_EXTENSIVE_LISTENING_A_PROMISING_COLLABORATION_ TO ENHANCE ${ }^{-}$LISTENING $\overline{-}$ SKILL (accessed date: 15.11 .2020$)$.

10. Syaifudin M. Improving Students Speaking Skill by Implementing Blended Learning (Online Learning and Classroom). Jurnal Informa. 2017. Vol. 3. N. 2. P. 30-34. URL: https://informa.poltekindonusa.ac.id/index.php/informa/article/ view/19 (accessed date: 15.11.2020). 